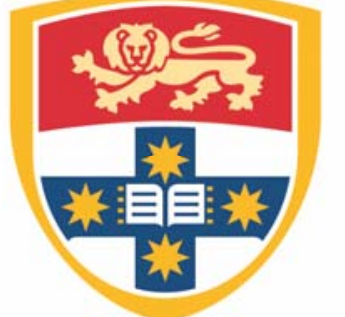

THE UNIVERSITY OF

SYDNEY

Economics Working Paper Series

$$
2015-19
$$

The Effect of Risk Sharing on Asset Prices: Natural Experiment from the Chinese Stock Market Liberalization

Mark K. Chan \& Simon Kwok 


\title{
The Effect of Risk Sharing on Asset Prices: Natural Experiment from the Chinese Stock Market Liberalization
}

\author{
Marc K. Chan \\ University of Technology Sydney \\ Simon Kwok
The University of Sydney *
}

September 2015

\begin{abstract}
In a recent stock market reform, over half of the stocks listed in the Shanghai Stock Exchange became purchasable by foreign investors. Theory predicts that the price revaluation of an investible stock should be positively associated with the reduction in systematic risk. Using the policy as a natural experiment, we test this implication using a difference-in-differences estimator and a sample of 786 stocks in the Shanghai market. We find that risk-sharing explains over 40 percent of the price revaluation of investible stocks during the eight-month window between reform announcement and implementation. The results support the efficiency of the Chinese stock market, to the extent that the reduction of systematic risk is priced into those stocks that are affected by the liberalization.
\end{abstract}

JEL CLASSIFICATION: G12, G15, G18

Keywords: Chinese stock market, liberalization, natural experiment, risk sharing, asset pricing

${ }^{*}$ Chan: University of Technology Sydney, UTS Business School, Sydney, Ultimo NSW 2007, Australia; Email: marc.chan@uts.edu.au. Kwok: School of Economics, Merewether Building, The University of Sydney, NSW 2006 Australia; Email: simon.kwok@sydney.edu.au. 


\section{Introduction}

In recent years, China has included financial market liberalization as one of the top priorities in its reform agenda. Despite recent attempts to liberalize its financial and foreign exchange systems, China's capital account remains relatively closed and the country accounts for less than three percent of global holdings of cross-border assets and liabilities. Although the literature has found evidence for the impact of financial market liberalization on the cost of equity capital (e.g., Bekaert and Harvey (2000) and Henry (2000)) and wider aspects of economic welfare (see Henry (2007) for an overview), direct evidence regarding China, the largest emerging market economy, remains scarce.

In this paper, we attempt to contribute an important piece of evidence in this area by analyzing a unique financial reform in China. The reform, known as Shanghai-Hong Kong Stock Connect, allows over half of the stocks listed in the Shanghai Stock Exchange (SSE) to be purchasable by foreign investors. Unlike preexisting schemes which are non-anonymous and highly restrictive in cross-border fund flows, investors can trade these stocks anonymously on a centralized trading platform set up by SSE and Hong Kong Stock Exchange (HKEX), subject to a overall quota of 250 billion yuan (40 billion USD). Given that the SSE is the largest stock market that has remained segmented from the rest of the world, the reform presents a particularly valuable opportunity to enrich the existing evidence on stock market liberalization, particularly in emerging economies. ${ }^{1}$

Our empirical strategy follows an important insight by Chari and Henry (2004). Asset pricing theory predicts that an asset's expected return should be positively associated with its exposure to systematic risk. However, empirical evidence that support this prediction has been mixed, as it is often found that systematic risk is not priced cross-sectionally (e.g., Fama and French (2004)). Chari and Henry (2004) note that stock market liberalizations reduce systematic risk because the relevant source of systematic risk becomes the world market; therefore, liberalizations represent an exogenous change from which we can test the prediction

\footnotetext{
${ }^{1}$ In recent years, the policy-experiment approach has been advocated as a clean source of identification of policy effects (Henry (2007)). A prevailing empirical approach is to analyze cross-country time-series data using various measures of liberalization as the principal source of policy variation (e.g., Bekaert and Harvey (2000), Henry (2000), Bekaert et al. (2001), Harrison et al. (2004), Bekaert et al. (2005), Galindo et al. (2007)). Because the findings can be sensitive to country coverage, sample periods, and indicators of liberalization (Eichengreen (2001)), care must be taken to control for various confounding factors.
} 
from theory. Using CAPM, they show that the reduction of the expected return of an asset upon liberalization is directly proportional to $D I F C O V$, which is defined as the covariance of the asset's returns with the local market minus the covariance of its returns with the world market. ${ }^{2}$ They then construct a sample of 410 firms from 11 emerging economies that liberalized their stock markets between 1989 and 1992. Because most countries retained some firms as noninvestible by foreigners, they are able to estimate a difference-in-differences model, using noninvestible firms as a control group. They find that the reduction in systematic risk accounted for roughly two-fifths of stock price revaluation in the implementation month of liberalization.

The most distinctive feature of our approach is that we conduct a microscopic analysis on one market. By focusing on an important liberalization episode in one large market, our analysis complements the broader evidence in the existing literature, which has pooled data from multiple markets but has yet produced conclusive evidence for any single market. Our evidence is valuable given the difficulty in identifying clean liberalization episodes and collecting comprehensive firm-level data in many emerging economies. Our data, which consists of 786 stocks in the Shanghai market, has the following distinctive features: ${ }^{3}$ (1) the reform announcement and implementation dates are very precise and reasonably close to each other (eight months), with no other major policies announced in between; (2) the reform rule clearly defines the set of stocks that are purchasable by foreign investors; (3) our sample selection procedure is based on all stocks listed in the market. The above features overcome the difficulties faced by Chari and Henry (2004), namely, the reform announcement dates are extremely hard to identify, the set of investible stocks are proxied by stocks in an investibility index, and the sample selection procedure is based on stocks in a global index. ${ }^{4}$

Using a natural experiment, we integrate the literature of stock market liberalization with the literature of asset pricing in the Chinese market. The existing literature on the

\footnotetext{
${ }^{2}$ They note that a fall in the the firm's expected return will cause an increase in its stock price, therefore the liberalization delivers a testable, cross-sectional implication of the theory. Their model considers complete and partial liberalizations. The institutional background of our empirical analysis resembles a partial liberalization, in particular that domestic investors have no access to the world market; see Section 2 for more details.

${ }^{3}$ We focus on firms that are not cross-listed; see Sections 2 and 3 for more details. Our companion paper (Chan and Kwok (2015)) uses vector error-correction models to exclusively analyze the effects on cross-listed stocks.

${ }^{4}$ These features also address a general concern in the earlier literature including Bekaert and Harvey (2000) and Henry (2000).
} 
Chinese market has largely focused on the role of market imperfections in explaining the price disparities between different share classes. Yet almost all the market capitalization in the Mainland market are composed of one type of shares (A-shares), which is closed to the world market except through special channels. ${ }^{5}$ Relatively few studies have analyzed how A-shares are priced. An exception is Eun and Huang (2007), who use data on A-shares from 1991 to 2004 to analyze the determinants of cross-sectional variation in average stock returns. They find that systematic risk (beta) is not priced cross-sectionally. However, they find other firm-level characteristics that can explain the expected returns, which lead them to conclude that stocks are priced rather rationally in China. Our study complement Eun and Huang (2007) by drawing on a unique liberalization to reveal the relationship between systematic risk and the pricing of A-shares in China. Our evidence is based on a recent period, which oversaw significant developments in the overall market and regulatory environments since the time frame considered by their study. These features allow us to provide a fresh perspective on the properties of the Chinese market.

We find strong evidence that risk sharing contributed significantly to price revaluation, even before the policy was implemented. During the eight-month window between reform announcement and implementation, the observed average monthly return among investible stocks is 4.25 percent, and the monthly return explained by risk sharing is 1.89 percent. Therefore, risk sharing explains over 40 percent of the price revaluation of investible stocks. This estimate is similar to Chari and Henry (2004) despite differences in the data and time window used for estimation. Extending their work, we perform quantile regressions and find that the risk-sharing mechanism is important in explaining price revaluation in the majority of the deciles of the stock returns distribution. Somewhat surprisingly, we find mixed evidence regarding the role of risk sharing in price revaluation during the first six months following implementation; either the news of liberalization has been absorbed prior to implementation, or other factors may have diluted the effects of risk sharing during this period. ${ }^{6}$

\footnotetext{
${ }^{5}$ A-shares are denominated in Renminbi. Prior to Shanghai-Hong Kong Stock Connect, foreign investment on A-shares was only allowed through a tightly-regulated structure known as QFII (see Section 2). A small number of firms issue B-shares, which are open to foreign investors. Some firms that are listed in the Mainland market also issue H-shares in the Hong Kong market. See, for instance, Sun and Tong (2000) and Chan et al. (2008) on the relative pricing of A- and B-shares. Examples of recent studies on the relative pricing of A- and H-shares include Wang and Jiang (2004), Cai et al. (2011), Chang et al. (2013), and Chung et al. (2013).

${ }^{6}$ Using a separate sample consisting of cross-listed stocks, Chan and Kwok (2015) find that the level of price disparity between A-shares in the Shanghai market and H-shares in the Hong Kong market widened
} 
The paper proceeds as follows. Section 2 discusses the policy background of ShanghaiHong Kong Stock Connect. Section 3 describes the theoretical motivation of our approach. Section 4 discusses the data used for estimation. Section 5 reports the main estimation results and sensitivity analysis. Section 6 concludes.

\section{Policy Background}

The stock markets in Mainland China have experienced dramatic growth in the past decade. ${ }^{7}$ This was accompanied by deep changes in the overall market and regulatory environments. In this section, we will provide a brief overview of Shanghai-Hong Kong Stock Connect and related developments in recent years.

Prior to Shanghai-Hong Kong Stock Connect, there were two programs that dominated cross-border investments between the stock markets in Mainland China and the world market. The Qualified Foreign Institutional Investor (QFII) program, which started in 2002, allows foreign institutional investors to invest in Mainland China's securities markets. The Qualified Domestic Institutional Investor (QDII) program, which started in 2006, allows institutional investors in Mainland China to invest in financial markets abroad. In both programs, investment quotas were allocated to institutional investors only. These quotas were gradually increased over the past decade; in 2014, the total quotas for QFII and QDII were 53.5 and 86.5 billion US dollars, respectively.

The QFII program underwent an extension in 2011. Formally known as the Renminbi Qualified Foreign Institutional Investor (RQFII) program, foreign institutional investors are permitted to invest in Mainland China's securities via offshore Renminbi accounts. RQFII started in Hong Kong in December 2011. Quotas were initially allocated to a number of companies, all of which were subsidiaries of mainland asset managers. ${ }^{8}$ In February 2014, the outstanding quota issued to RQFII was 180.4 billion yuan (29.4 billion USD), and the investors were mainly composed of Hong Kong subsidiaries of Mainland fund management substantially during the post-implementation period. However, the prices of A-shares and H-shares are cointegrated as opposed to the pre-announcement period. This provides evidence that market segmentation reduces upon liberalization, while the full picture remains to be analyzed.

${ }^{7}$ The Mainland market has two stock exchanges (Shanghai and Shenzhen). Firms can only list in either the Shanghai or the Shenzhen market.

${ }^{8}$ RQFII had an initial quota ceiling of 20 billion yuan (3.1 billion USD). Since then, the RQFII program has been extended to financial institutions in London, Singapore and Paris, to name a few. 
companies and securities companies.

The prospect of market segmentation was fundamentally changed by the recent announcement of Shanghai-Hong Kong Stock Connect. The announcement of the pilot program was made on April 10, 2014. ${ }^{9}$ Under the program, the mechanism of cross-border investment is fundamentally different from preexisting schemes. Through a centralized platform set up by the Shanghai Stock Exchange (SSE) and Hong Kong Stock Exchange (HKEX), institutional and noninstitutional investors can perform trading on a subset of stocks that are listed in either market, while retaining anonymity and circumventing the current foreign exchange controls in China. In particular, Hong Kong and international investors can directly purchase $A$-shares in the Shanghai market, which are denominated in Renminbi and had been restricted to Mainland Chinese (except through QFII, RQFII and QDII). ${ }^{10}$ Investment in the Shanghai market is subject to a daily quota of 10.5 billion yuan (1.68 billion USD) and an overall quota of 250 billion yuan (40 billion USD), or around 2 percent of the total market capitalization in the Shanghai market.

The list of stocks that are investible by Hong Kong and international investors include constituent stocks in the SSE180 Index and SSE380 Index, and stocks that are cross-listed on both the Shanghai and Hong Kong markets. ${ }^{11}$ The SSE180 Index consists of 180 of the most representative stocks on SSE based on sector representation, size and liquidity. The SSE380 Index consists of 380 stocks with midcap, high growth and good earning records. There is no overlap between both indices. The non-crosslisted investible stocks, which are the focus of our paper, constitute slightly over half of all the listed stocks in the Shanghai market.

Under the program, Mainland investors with at least 500,000 yuan (80,645 USD) in securities or cash are also allowed to invest in the Hong Kong market, subject to a daily

\footnotetext{
${ }^{9}$ The announcement was made by Chinese Premier Li Keqiang. Using longitudinal data on daily stock prices of cross-listed firms between the Shanghai and Hong Kong stock exchanges from 2002 to 2014, Chan and Kwok (2014) find that the announcement of Shanghai-Hong Kong Stock Connect on April 10, 2014 was accompanied by an unprecedented abrupt convergence in price disparity (seven deviations away from the historical average) during the same day. This supports a clear distinction between pre- and post-announcement periods in this liberalization episode.

${ }^{10}$ In the Shanghai market, a small number of firms also issued B-shares, which have been purchasable by foreigners. These shares constitute a very small portion of the total market capitalization and are not the subject of our research.

${ }^{11}$ In 2014, there are around 65 cross-listed firms that issued both A-shares (Shanghai) and H-shares (Hong Kong). Almost all of these A-shares belong to either the SSE180 or SSE380 Index. These stocks are not considered in this paper. A separate empirical analysis for cross-listed stocks can be found in Chan and Kwok (2015).
} 
quota of 13 billion yuan and an overall quota of 300 billion yuan (48 billion USD). However, because the trading platform is limited to selected stocks in the Hong Kong market only, they are unable to use their funds to invest in other markets. Therefore, the world market portfolio remains out of reach for domestic investors. As discussed in subsequent sections, this asymmetry allows us to estimate the effects of risk sharing on the Shanghai market via a natural experiment approach.

In summary, Shanghai-Hong Kong Stock Connect represents a significant step towards China's capital control liberalization. The launch of the program on November 17, 2015 culminated a whole new policy environment relative to the past. Furthermore, the program enables regular "northbound" investment activities, thus realizing the large demand for mainland securities by Hong Kong and international investors.

\section{Theoretical Motivation}

Our model follows that of Chari and Henry (2004). We focus on the market's response to the news of a liberalization policy that opens a subset of the domestic market to foreign investors, while domestic investors have no access to the world market portfolio. ${ }^{12}$ All investors in the world are assumed to be risk averse and have a common relative risk aversion parameter $\gamma$. They care only about the mean and volatility of their investment portfolios. As a result, individual stocks are priced according to the CAPM. Denote $M$ the domestic market portfolio and $W$ the world market portfolio. Also let $I$ (respectively, $N$ ) be the group of investible (non-investible) stocks eligible (ineligible) for purchase by foreign investors under the new policy.

Prior to market liberalization, foreign investors are excluded from the domestic (i.e., SSE) market, and the domestic stocks are solely held by domestic investors. The stock $i$ 's expected return $E\left(R_{i, M}\right)$ takes the following single-beta representation

$$
E\left(R_{i, M}\right)=R_{M}^{f}+\beta_{i, M}\left[E\left(R_{M}\right)-R_{M}^{f}\right],
$$

\footnotetext{
${ }^{12}$ This corresponds to the classification of strong segmentation under partial liberalization in Chari and Henry (2004). It is assumed that the policy was announced on a clear-cut date, and that there are no other confounding factors apart from the policy announcement.
} 
where $R_{M}^{f}$ is the risk-free rate in the domestic market, $E\left(R_{M}\right)$ is the expected return of the domestic market portfolio, and $\beta_{i, M}$ is the stock $i$ 's beta coefficient with respect to the domestic market portfolio. Since the market is closed, all domestic stocks are exposed to the same systematic risk of the domestic market portfolio, which yields an excess mean return of $E\left(R_{M}\right)-R_{M}^{f}$, although the degree of exposure varies among stocks according to the beta coefficient $\beta_{i, M}$. By investing in stock $i$, the domestic investor, having the relative risk aversion parameter $\gamma$, is compensated with a risk premium of $\beta_{i, M}\left[E\left(R_{M}\right)-R_{M}^{f}\right]=\beta_{i, M} \gamma \sigma_{M}^{2}$, where $\sigma_{M}^{2}$ is the variance of the domestic market portfolio's return.

After the policy is announced, domestic investors will adjust their expectations in anticipation of market liberalization. In particular, they expect that, for investible stocks, the source of systematic risk will change from the domestic market portfolio to the world portfolio, as the systematic risk will be borne by all investors. This adjustment is reflected in the expected required return $E\left(R_{i, W}\right)$ of investible stock $i \in I$, given by

$$
E\left(R_{i, W}\right)=R_{W}^{f}+\beta_{i, W}\left[E\left(R_{W}\right)-R_{W}^{f}\right], \quad i \in I,
$$

where $R_{W}^{f}$ is the risk-free rate in the world market, $E\left(R_{W}\right)$ is the expected return of the world market portfolio, and $\beta_{i, W}$ is the stock $i$ 's beta coefficient with respect to the world market portfolio. The risk premium associated with stock $i \in I$ is $\beta_{i, W}\left[E\left(R_{W}\right)-R_{W}^{f}\right]=\beta_{i, W} \gamma \sigma_{W}^{2}$, where $\sigma_{W}^{2}$ is the variance of the world market portfolio's return.

Subtracting (2) from (1), and using the definition of the beta coefficients ${ }^{13}$, we obtain the change in expected required return $\Delta E\left(R_{i}\right):=E\left(R_{i, M}\right)-E\left(R_{i, W}\right)$ of investible stock $i \in I$ as a result of the policy announcement, given by

$$
\Delta E\left(R_{i}\right)=\Delta R^{f}+\gamma D I F C O V_{i}, \quad i \in I,
$$

where $\Delta R^{f}=R_{M}^{f}-R_{W}^{f}$ and $D I F C O V_{i}$ is defined as

$$
\begin{aligned}
\operatorname{DIFCOV}_{i} & =\operatorname{Cov}\left(R_{i, M}, R_{M}\right)-\operatorname{Cov}\left(R_{i, W}, R_{W}\right) \\
& =\beta_{i, M} \sigma_{M}^{2}-\beta_{i, W} \sigma_{W}^{2} .
\end{aligned}
$$

\footnotetext{
${ }^{13}$ The beta coefficient of stock $i$ with respect to portfolio $P$ (where $P=M$ or $W$ ) is defined as $\beta_{i, P}=$ $\operatorname{Cov}\left(R_{i, P}, R_{P}\right) / \sigma_{P}^{2}$.
} 
From (3), we see that the change in expected required return of investible stocks is achieved through a uniform change in the risk-free rates represented by the intercept $\Delta R^{f}$, and a heterogeneous change in the exposure to the systematic risk, as captured by the factor DIFCOV . $_{\text {. }}$ From (4), it is clear that the heterogeneity of $D I F C O V_{i}$ comes from the varying exposure of different firms to the systematic risk (as measured by the beta coefficients), despite a uniform shift of the systematic risk from the domestic market portfolio to the world portfolio (as measured by $\sigma_{M}^{2}$ and $\sigma_{W}^{2}$ ).

However, the above policy implication does not hold for stocks that are inaccessible to foreign investors. For non-investible stocks, the systematic risk remains to be from the domestic market, and they will not subject to the same shift in systematic risk as the one applied to investible stocks. ${ }^{14}$ The absence of risk-sharing mechanism entails that non-investible stocks will not be revaluated according to (3), i.e., $D I F C O V_{i}$ will have no impact on the expected required return for stock $i \in N$. Assuming the absence of other confounding factors around the policy announcement, the change in expected required return for stock $i \in N$ is given by

$$
\Delta E\left(R_{i}\right)=\Delta R^{f}, \quad i \in N
$$

Combining with (3), we obtain

$$
\Delta E\left(R_{i}\right)=\Delta R^{f}+\gamma D I F C O V_{i} * \text { Invest }_{i}
$$

where Invest $_{i}$ is a dummy variable that is equal to 1 if $i \in I$ and 0 otherwise.

\section{Data}

Our analysis sample consists of 786 non-crosslisted stocks in the Shanghai Stock Exchange (SSE). We consider A-shares, which constitute almost all the market capitalization in SSE and are all denominated in Renminbi. The analysis sample is constructed from the following procedure. In early 2015, there were around 1050 stocks listed on SSE. Around 6 percent of the stocks are dropped because they are cross-listed between the Shanghai and Hong Kong

\footnotetext{
${ }^{14}$ It was shown by Hietala (1989) that the portfolio of domestic investors will be tilted towards non-investible stocks right after liberalization to strong segmentation; however, the associated empirical evidence is not clear (Chari and Henry, 2004).
} 
markets. We also drop stocks that had an initial public offering after April 2012 (13 percent), stocks that had suspended trading for at least two months prior to the end of Nov 2014 (4 percent), and stocks with missing data (2 percent). According to the rules of Shanghai-Hong Kong Stock Connect, 316 stocks are noninvestible and 470 stocks are investible in the analysis sample. Among the investible stocks, 130 belong to the SSE180 index and 340 belong to the SSE380 index. We use the historical monthly return series of each stock to compute its covariance with the local and world markets. The local and world markets are represented by the SSE Composite Index and the MSCI World Index, respectively. Return is defined as the first difference of the natural logarithm in dividend-inclusive price (or index). Historical monthly returns for five years prior to the starting month of the analysis are used to compute the covariances. ${ }^{15}$ In the baseline specification, the starting month of the analysis is April 2014 (announcement month). We also use the series to compute other summary statistics such as the standard deviation of stock returns.

Table I reports the key summary statistics for noninvestible stocks and investible stocks, respectively. For an average noninvestible stock, the covariances of its returns with the local and world markets are 0.0049 and 0.0013 , respectively. For an average investible stock, the corresponding covariances are 0.0046 and 0.0012 , respectively. Therefore, for both types of stocks, the covariance with the local market is roughly 3.8 times larger than the covariance with the world market. The key variable DIFCOV is defined as the covariance with the local market minus the covariance with the world market. The average DIFCOV is 0.0037 among noninvestible stocks and 0.0034 among investible stocks.

To better understand the size of DIFCOV, it is useful to look at additional summary statistics. From equation (4), DIFCOV $V_{i}=\left(\rho_{i M} \sigma_{M}-\rho_{i W} \sigma_{W}\right) \sigma_{i}$, where $\rho_{i M}$ is the correlation of the stock with the local market, $\rho_{i W}$ is the correlation of the stock with the world market, $\sigma_{i}$ is the standard deviation of stock $i$ 's return, $\sigma_{M}$ is the standard deviation of the local market return, and $\sigma_{W}$ is the standard deviation of the world market return. The standard deviation of the local market return is 0.055 , which is slightly larger than the standard deviation of the world market return at 0.041. By contrast, individual stock returns are much more correlated with the local market than the world market. For an average noninvestible stock, the correlation of its returns with the local and world markets are 0.7621 and 0.2629,

\footnotetext{
${ }^{15}$ For stocks with a shorter history, we use the monthly returns up to the date of initial public offering.
} 
respectively. For an average investible stock, the corresponding numbers are 0.7566 and 0.2626 , respectively.

The subsequent rows in the table indicate that relative to noninvestible stocks, investible stocks have a larger size, similar turnover, higher book-to-market ratio, and a higher fraction of shares held by institutional investors. ${ }^{16}$ During the period between April 2014 (announcement) and November 2014 (implementation), the average monthly returns for noninvestible and investible stocks are 4.94 and 4.25 percent, respectively. By contrast, during the five years prior to April 2014, the average monthly returns are 0.48 and 0.33 percent, respectively. These summary statistics are broadly consistent with Henry (2000), who find that stock markets experienced an average abnormal return of 4.7 percent per month during an eight-month window leading up to the implementation of a country's initial stock market liberalization. ${ }^{17}$

It is potentially interesting to compare our data with Chari and Henry (2004), which is based on a different background. Their empirical analysis is based on firm-level data from 11 emerging countries that liberalized their stock markets between 1989 and 1992. Their sample consists of 172 noninvestible stocks and 238 investible stocks. ${ }^{18}$ Because their sample is based on stocks in the International Finance Corporation Global Index (IFCG), the stocks tend to be larger and are more actively traded in their local markets. Investible stocks are defined to be the subset of stocks in the IFCG that are also in the IFC Investible Index (IFCI). To be part of IFCI, the stock has to be legally purchasable by foreigners, and has a minimum investible market capitalization of $\$ 50$ million and has traded at least $\$ 20$ minimum over the prior year. Therefore, their definition of investibility is more restrictive than ours.

In their sample, the average DIFCOV for noninvestible and investible stocks are 0.010 and 0.018, respectively. Therefore, their sample exhibits not only a higher level of DIFCOV but also a large difference in DIFCOV between both types of stocks. The high average DIFCOV is due to the fact that the stock markets in their sample are highly heterogeneous, in particular,

\footnotetext{
${ }^{16}$ In the table, size is defined as the market capitalization of the stock as a proportion to that of the market portfolio. Turnover is defined as the ratio of total dollar value of the stock traded over the year divided by the firm's market capitalization.

${ }^{17}$ His analysis is based on a sample of 12 emerging countries. After controlling for various factors, the average abnormal return is 3.3 percent per month over the same horizon.

${ }^{18}$ The countries and sample sizes (noninvestible, investible) are Argentina (10, 14), Brazil (23, 21), Chile $(17,9)$, Colombia $(15,5)$, India $(23,39)$, Korea (6, 66), Mexico (27, 4), Pakistan (38, 3), Taiwan (0, 63), Turkey $(5,9)$, and Venezuela $(8,5)$.
} 
several markets are highly volatile relative to the Chinese market. The stocks in their sample exhibit very small covariances with the world market.

Another feature of our data is that we are able to locate the exact policy announcement date (April 10, 2014) and implementation date (November 17, 2014). As a result, we are able to define clearly the period between announcement and implementation, and the period after implementation. If the market reflects the news promptly, we should expect a substantial effect before implementation. By contrast, the data in Chari and Henry (2004) can only locate the implementation month of each liberalization, and it is unknown how much earlier the news was announced prior to implementation. Nevertheless, as discussed in Henry (2000), who analyzed similar liberalization episodes, it is extremely difficult to collect verifiable data on policy announcement dates. ${ }^{19}$ Because Chari and Henry (2004) focus on the effects during the implementation month, we expect their estimates to represent a lower bound of the overall effects of the policy.

\section{$5 \quad$ Empirical Results}

We first investigate the graphical relationship between DIFCOV and stock price revaluation, which is defined as the average monthly return between April and November 2014. In contrast to Chari and Henry (2004) where country-specific fixed effects may confound the visual relationship, our graphs provide more direct evidence by focusing on a single market. We see that noninvestible stocks (Figure 1(a)) show no linear association between DIFCOV and stock price revaluation. By contrast, among investible stocks (Figure 1(b)), a higher DIFCOV is associated with a larger stock price revaluation. Therefore, the graphical evidence is consistent with the prediction from theory.

The relationship is investigated formally using a difference-in-differences (DID) model as follows:

$$
\begin{aligned}
& \Delta \ln \text { Price }_{i j}=\alpha_{0}+\alpha_{1} \text { Invest }_{i j}+\alpha_{2} \text { DIFCOV } i j+\alpha_{12}\left(\text { Invest }_{i j} * D I F C O V_{i j}\right) \\
& +\boldsymbol{X}_{i j} \gamma+\text { Industry }_{j}+\epsilon_{i j} .
\end{aligned}
$$

\footnotetext{
${ }^{19}$ Bekaert and Harvey (2000) also acknowledge the importance of the announcement effect of liberalization policies because of rational expectations of market participants. In their analysis, they have actual announcement dates for some ADRs. When announcement dates are unavailable, a proxy is used.
} 
The model largely follows Chari and Henry (2004). ${ }^{20} \Delta \ln$ Price $_{i j}$ is the return for stock $i$ in industry $j$ Invest $_{i j}$ is a dummy variable that equals one if the stock is investible and zero otherwise, DIFCOV $i j$ is the stock's DIFCOV defined in the data section, $\boldsymbol{X}_{i j}$ is a vector of additional stock characteristics, and Industry $y_{j}$ captures the industry fixed effect. ${ }^{21}$ In the DID setup, investible stocks form the treatment group and noninvestible stocks form the control group. Among investible stocks, a higher DIFCOV represents a larger reduction in systematic risk, which implies a larger stock price revaluation. By contrast, the repricing of noninvestible stocks should not depend on DIFCOV. Therefore, there are two testable implications from theory: (1) the coefficient $\alpha_{2}$ should not be significantly different from zero; and (2) the treatment effect $\alpha_{12}$, which captures the risk-sharing mechanism, should be positive. Theory also predicts that the liberalization will generate a common positive shock on prices through a reduction in the risk-free rate of the local market. If the stock characteristics are fully controlled for by $\boldsymbol{X}_{i j}$ and Industry ${ }_{j}$, then the coefficient $\alpha_{1}$ should not be significantly different from zero.

Table II reports the difference-in-difference regression estimates across four specifications, using the average monthly return between April and November 2014 as the dependent variable. $^{22}$ In Column 1, there are no industry fixed effects and no controls for additional stock characteristics. The coefficient on DIFCOV $\left(\alpha_{2}\right)$ is 0.191 and is statistically insignificant. The DID coefficient $\left(\alpha_{12}\right)$ is 3.797 and is statistically significant at the five percent level. Therefore, the evidence is in support of the risk-sharing mechanism in the repricing of investible stocks. The coefficient on Invest $\left(\alpha_{1}\right)$ is -0.02 and is statistically significant at the 1 percent level. This implies that if a stock has a zero DIFCOV, being investible will negatively affect its return. However, the coefficient may have just picked up the effects of other characteristics that are not controlled for in the regression. The intercept coefficient $\left(\alpha_{0}\right)$ is 0.049 and is statistically significant at the 1 percent level. This implies that a noninvestible stock with a zero DIFCOV will experience an average of 4.9-percent increase in price per month.

\footnotetext{
${ }^{20}$ They note that a fall in the the firm's expected return will cause an increase in its stock price; therefore, the empirical model is able to test the implication from theory.

${ }^{21}$ Chari and Henry (2004) use a country fixed effect in their empirical specification, and they do not use industry fixed effects. In our data, there are a total of ten industries.

${ }^{22}$ The average monthly return is used as the dependent variable because it provides a more consistent measure of stock performance over the period. Single month returns are subject to more fluctuations because focus on just one market.
} 
The subsequent specifications include more controls for stock characteristics. Column 2 includes industry fixed effects. The estimates remain similar, with the DID coefficient becoming slightly larger at 3.982. In column 3, we follow the specification in Chari and Henry (2004) by controlling for size and turnover and interact both variables by investibility status. ${ }^{23}$ In particular, this addresses the concern that the effect of risk sharing may be misrepresented as foreigners may have purchased investible stocks based on size and liquidity, which are potentially correlated with DIFCOV. The DID coefficient is 3.721 and remains statistically significant at the 5 percent level. The coefficient on Invest becomes statistically insignificant, which suggests that size and liquidity are potentially important control variables. Liquidity has a negative significant effect on the revaluation of both types of stocks. Column 4 expands the specification by controlling for other characteristics including book-to-market ratio, share of institutional investors, and the stock's historical return and volatility. These characteristics are interacted with investibility status. The results indicate that historical performance explain some of the returns of noninvestible stocks. The DID coefficient becomes higher at 5.56, and is statistically significant at the 1 percent level. By contrast, the coefficients on Invest and DIFCOV are statistically insignificant.

Among investible stocks, the average DIFCOV is 0.0034 , and the average price revaluation is 4.25 percent per month between April and November 2014. The DID estimate in Column 5 implies that risk sharing explains $0.0034 * 5.56=0.0189$ or 1.89 percent per month of price revaluation among investible stocks during this period. Therefore, risk sharing explains $1.89 / 4.25=44.5$ percent of price revaluation among investible stocks during this period. This is similar to Chari and Henry (2004), who find that roughly two-fifths of the total revaluation can be explained by the reduction in systematic risk due to liberalization.

\footnotetext{
${ }^{23}$ For each of these characteristics, we adopt their interaction specification of $\gamma_{1}(X *$ Invest $)+\gamma_{2}(X *(1-$ Invest)). Therefore, the marginal effect of $X$ is $\gamma_{2}$ among noninvestible stocks and it is $\gamma_{1}$ among investible stocks. The interaction effect in the usual sense is $\gamma_{1}-\gamma_{2}$.
} 


\subsection{Sensitivity Analysis}

\subsubsection{Effects over Different Sample Periods}

In this section, we report several sensitivity analysis that can shed more light on the risksharing mechanism. ${ }^{24}$ Table III reports estimation results from three alternative sample periods. For each sample period, we report two specifications, one controlling for industry fixed effects only and the other including the full set of covariates. Columns 1a and 1b consider October 2013 to March 2014, which covers a six-month window prior to policy announcement. Because it is a pre-announcement period, DIFCOV should play no role in explaining the returns of investible and noninvestible stocks. We find that in both specifications, the DID coefficient is small and statistically insignificant. ${ }^{25}$ Columns $2 \mathrm{a}$ and $2 \mathrm{~b}$ consider a six-month window leading up to November 2014. The DID coefficient is similar in size to the baseline estimates and remain statistically significant at the 5 percent level. Columns 3a and 3b consider a six-month window starting from November 2014. It analyzes whether risk-sharing continues to play a role in the price revaluation of investible stocks during the post-implementation period. We find that the DID coefficient becomes statistically insignificant, which suggests that price revaluation due to risk-sharing mainly took place before policy implementation. It is worthwhile to note that stock prices continued to increase during the post-implementation period - the average monthly returns of noninvestible and investible stocks are 4.95 and 6.17 percent, respectively. Nevertheless, according to the DID model, the risk-sharing mechanism does not explain much of these returns.

\subsubsection{Quantile Regression}

Table IV reports estimation results from quantile regressions of stock price revaluation. Using quantile regression, we can investigate whether the risk-sharing mechanism plays a more important role in specific parts of the stock return distribution, and perform a robustness check on whether the previous results are driven by outliers. Quantile regression is possible

\footnotetext{
${ }^{24}$ Our results are robust to a number of additional sensitivity analysis that are not reported in this paper. These include but are not limited to sample construction (e.g., IPO dates) and more types of sample periods. For instance, we consider a sample period covering a nine-month period from April to December 2014; details can be found in Appendix Table A2.

${ }^{25}$ During this period, the average monthly returns of noninvestible and investible stocks are 0.54 percent and -0.76 percent, respectively.
} 
in our context because we have a large sample of stocks sharing a similar institutional background under one market. In Panel A, we consider the sample period between April 2014 and November 2014. In Panel B, we consider the six-month window leading up to November 2014. In both Panels, estimation results from all deciles (i.e., every 10th percentile of the distribution) are reported. Due to concerns for numerical convergence of the estimation method, the quantile regressions contain only the essential regressors including Invest, DIFCOV, Invest $*$ DIFCOV , and industry fixed effects. The coefficients are interpreted as follows. For instance, in a 0.5 quantile (i.e., median) regression, the intercept can be interpreted as the predicted 50th percentile (i.e., median) of stock return when the above regressors are all zero; a slope coefficient can be interpreted as the predicted change in the 50th percentile (i.e., median) of stock return when the regressor is changed by one unit.

Both Panels indicate that the risk-sharing mechanism is prevalent in most parts of the stock return distribution. The results from Panel A suggest that the risk-sharing mechanism is more significant in the lower and upper quantiles of the stock return distribution. For instance, in the 0.2 and 0.8 quantile regressions, the DID coefficients are 3.826 and 4.005, respectively, and they are both statistically significant. By contrast, the DID coefficient becomes smaller and statistically insignificant toward the median of the distribution. Panel B shows a slightly different picture. The DID coefficient is large and statistically significant from the 0.3 quantile regression to the 0.9 quantile regression. However, in the bottom part of the return distribution ( 0.1 and 0.2 quantiles), the DID coefficient is smaller and becomes statistically insignificant.

\subsubsection{Further Classification of Investible Stocks}

The investible stocks in our sample belong to either the SSE380 Index or SSE180 Index. The characteristics of constituent stocks in SSE380 and SSE180 indices are different and they may represent different targets for purchase by foreigners. We conduct sensitivity analysis on this issue by allowing the effects to be heterogeneous between both subsets of investible stocks.

The summary statistics of stocks in the SSE380 and SSE180 indices are reported in Appendix Table A1. The largest difference is size; stocks in the SSE180 Index are on average three times larger than stocks in the SSE380 Index. By contrast, there are no substantial differences in other characteristics. Table V reports the estimation results of the sensitivity 
analysis. In the table, Columns 1 to 3 focus on the baseline sample period between April and November 2014, and Column 4 focuses on the six-month window leading up to November 2014.

Column 1 excludes all SSE180 stocks from the sample. As a result, the sample size is 656, which consists of 316 noninvestible stocks and 340 investible stocks in the SSE380 Index. The DID coefficient is 4.863 and is statistically significant at the 5 percent level. Column 2 does the opposite by excluding all SSE380 stocks from the sample. The sample size becomes 446 with 316 noninvestible stocks and 130 investible stocks in the SSE180 Index. The DID coefficient is larger at 6.473 and is statistically significant at the 5 percent level. In both specifications, the coefficient on DIFCOV is small and statistically insignificant. These results suggest that the risk-sharing mechanism is significant for the price revaluation of both SSE380 and SSE180 stocks.

Column 3 considers all stocks in the sample, but the baseline specification is expanded to distinguish between SSE380 and SSE180 stocks as follows. First, it includes a dummy variable that equals one if the stock belongs to the SSE180 Index and zero otherwise. Second, it includes an interaction term between DIFCOV with the SSE180 dummy variable. Therefore, SSE180 stocks are allowed to have different average returns and different effects of risk-sharing from SSE380 stocks. The DID coefficient on DIFCOV*Invest is 4.727 and statistically significant at the 5 percent level. This coefficient captures the effect of risksharing among SSE380 stocks. The DID coefficient on DIFCOV *SSE180 is 3.044 and is statistically significant at the 10 percent level. Therefore, among SSE180 stocks, the effect of risk-sharing is the sum of the two DID coefficients, that is, $4.727+3.044=7.771$. The coefficients on Invest and SSE180 are both statistically insignificant. Column 4 uses the same specification as Column 3, but considers the six-month window leading up to November 2014. The DID coefficient on DIFCOV * Invest is 5.311 and statistically significant at the 5 percent level. The DID coefficient on DIFCOV *SSE180 is 2.087 and is statistically insignificant. Therefore, during this shorter time window, the effects of risk-sharing are not significantly different between SSE380 and SSE180 stocks. 


\section{Conclusion}

In this paper, we examined the role of risk sharing in stock price adjustment due to a unique liberalization policy applied to the Shanghai Stock Exchange. Utilizing Shanghai-Hong Kong Stock Connect as a natural experiment, we identified that risk sharing was a significant and robust determinant of the price revaluation of stocks that became eligible for purchase by foreign investors. The price adjustment occurred over a period as early as the policy announcement month and extended shortly beyond policy implementation, thus reflecting investors' expectation of the effect of market liberalization on stock prices. For investible stocks, more than 40 percent of the total stock price revaluation could be attributed to risk sharing through the reduction of systematic risk. Confirming the prediction from asset pricing theory, the size of price adjustment was firm-specific, and was determined by the amount of the firm's exposure to the market portfolio that shifted as a result of liberalization. Our result contributes to the literature by providing empirical evidence of risk sharing in an important reform in the history of Chinese stock markets.

The Shanghai Stock Exchange is the largest stock market among developing countries. It oversaw numerous episodes of wildly turbulent trading periods in which domestic investors felt the full weight of systematic shocks applied to their basket of stock investments. Over the past couple of decades, market liberalization policies have been gradually implemented in a concerted manner, including QFII, RQFII and QDII. From the perspective of risk-sharing, this series of market reforms seem to be heading in a healthy direction. As suggested by our analysis on the recent Shanghai-Hong Kong Stock Connect, the stock market seems to be efficient to the extent that the reduction of systematic market risk is rationally priced into those stocks that are expected to benefit from the policy. It is expected that similar future liberalization episodes will contribute to a more stable market through a more diversified market portfolio and investor pool in the long run.

\section{References}

Bekaert, G. And C. Harvey (2000): "Foreign Speculators and Emerging Equity Markets," Journal of Finance, 55, 565-613.

Bekaert, G., C. R. Harvey, and C. Lundblad (2001): "Emerging Equity Markets and Economic Development," Journal of development Economics, 66, 465-504. 
(2005): "Does Financial Liberalization Spur Growth?" Journal of Financial Economics, $77,3-55$.

Cai, C. X., P. B. McGuinness, and Q. Zhang (2011): "The Pricing Dynamics of CrossListed Securities: The Case of Chinese A- and H-shares," Journal of Banking and Finance, $35,2123-2136$.

Chan, K., A. Menkveld, and Z. Yang (2008): "Information Asymmetry and Asset Prices: Evidence from the China Foreign Share Discount," Journal of Finance, 63, 159-196.

Chan, M. And S. KwoK (2014): "Connecting the Markets? Recent Evidence on China's Capital Account Liberalization," Working Paper, University of Sydney.

- (2015): "Capital Account Liberalization and Dynamic Price Discovery: Evidence from Chinese Cross-Listed Stocks," Applied Economics, forthcoming.

Chang, E. C., Y. Luo, And J. Ren (2013): "Cross-Listing and Pricing Efficiency: The Informational and Anchoring Role Played by the Reference Price," Journal of Banking and Finance, 37, 4449-4464.

Chari, A. And P. Henry (2004): "Risk-Sharing and Asset Prices: Evidence from a Natural Experiment," Journal of Finance, 59, 1295-1324.

Chung, T.-K., C.-H. Hui, And K.-F. Li (2013): "Explaining Share Price Disparity with Parameter Uncertainty: Evidence from Chinese A- and H-Shares," Journal of Banking and Finance, 37, 1073-1083.

Eichengreen, B. (2001): "Capital Account Liberalization: What Do Cross-Country Studies Tell Us?" World Bank Economic Review, 15, 341-365.

Eun, C. And W. Huang (2007): “Asset Pricing in China's Domestic Stock Markets: Is there a Logic?" Pacific-Basin Finance Journal, 15, 452-480.

Fama, E. And K. French (2004): "The Capital Asset Pricing Model: Theory and Evidence," Journal of Economic Perspectives, 18, 25-46.

Galindo, A., F. Schiantarelli, and A. Weiss (2007): "Does Financial Liberalization Improve the Allocation of Investment? Micro Evidence from Developing Countries," Journal of Development Economics, 83, 562-587.

Harrison, A., I. Love, And M. McMillan (2004): "Global Capital Flows and Financing Constraints," Journal of Development Economics, 75, 269-301.

Henry, P. (2000): "Stock Market Liberalization, Economic Reform, and Emerging Market Equity Prices," Journal of Finance, 55, 529-564.

(2007): "Capital Account Liberalization: Theory, Evidence, and Speculation," Journal of Economic Literature, 45, 887-935.

Hietala, P. (1989): "Asset Pricing in Partially Segmenented Markets: Evidence from the Finnish Market," Journal of Finance, 44, 697-718. 
Sun, Q. And W. Tong (2000): "The Effect of Market Segmentation on Stock Prices: the China Syndrome," Journal of Banking and Finance, 24, 1875-1902.

WANG, S. AND L. JIANG (2004): "Location of trade, ownership restrictions, and market illiquidity: Examining Chinese A- and H-shares," Journal of Banking and Finance, 28, $1273-1297$. 
TABLE I

Summary Statistics of Key Variables ${ }^{\mathrm{a}}$

\begin{tabular}{lrrrr}
\hline \hline Variables & Mean & St.Dev. & Min & Max \\
\hline Noninvestible stocks $(N=316)$ : & & & & \\
Difcov & 0.0037 & 0.0011 & 0.0074 & 0.0066 \\
Covariance with local market & 0.0049 & 0.0012 & 0.0010 & 0.0085 \\
Covariance with world market & 0.0013 & 0.0006 & -0.0005 & 0.0036 \\
Correlation with local market & 0.5947 & 0.1156 & 0.3076 & 0.8473 \\
Correlation with world market & 0.2101 & 0.0952 & -0.1080 & 0.4518 \\
Size & 0.0003 & 0.0004 & 0.0001 & 0.0055 \\
Turnover & 2.2063 & 1.7649 & 0.0643 & 17.7168 \\
Book to market ratio & 0.3021 & 0.2207 & -0.0287 & 1.8189 \\
Institutional owner (\%) & 24.9023 & 22.7034 & 0.0000 & 84.7050 \\
Mean of historical monthly returns (damean) & 0.0048 & 0.0079 & -0.0194 & 0.0396 \\
Standard deviation of historical returns (dasd) & 0.1180 & 0.0213 & 0.0687 & 0.1962 \\
Monthly return between Apr-Nov 2014 & 0.0494 & 0.0280 & -0.0090 & 0.2004 \\
& & & & \\
Investible stocks (N=470): & & & & \\
Difcov & 0.0034 & 0.0013 & -0.0002 & 0.0066 \\
Covariance with local market & 0.0046 & 0.0017 & 0.0004 & 0.0088 \\
Covariance with world market & 0.0012 & 0.0006 & -0.0006 & 0.0029 \\
Correlation with local market & 0.5835 & 0.1545 & 0.0466 & 0.9117 \\
Correlation with world market & 0.2014 & 0.1178 & -0.1426 & 0.5380 \\
Size & 0.0008 & 0.0012 & 0.0001 & 0.0097 \\
Turnover & 2.2784 & 1.7216 & 0.1341 & 12.6923 \\
Book to market ratio & 0.4540 & 0.2476 & 0.0593 & 1.4390 \\
Institutional owner (\%) & 36.9103 & 25.5553 & 0.0100 & 100.0000 \\
Mean of historical monthly returns (damean) & 0.0033 & 0.0097 & -0.0247 & 0.0351 \\
Standard deviation of historical returns (dasd) & 0.1107 & 0.0223 & 0.0491 & 0.2055 \\
Monthly return between Apr-Nov 2014 & 0.0425 & 0.0256 & -0.0381 & 0.1571 \\
\hline Sirat & & & \\
\hline
\end{tabular}

${ }^{a}$ Size is defined as the market capitalization of the stock as a proportion to that of the market portfolio prior to the policy implementation date. Turnover is defined as the ratio of total dollar value of the stock traded over the year ended on Nov 16, 2013 divided by the firm's market capitalization. BooktoMarket is the ratio of the total book value to the market capitalization of the firm prior to the implementation date. Damean (Dasd) is the mean (standard deviation) of the monthly returns of the stock over the five years (or up to the IPO date, whichever is later) prior to April 2014. 
TABLE II

MAIN REGRESSION RESULTS ${ }^{\mathrm{a}}$

\begin{tabular}{|c|c|c|c|c|}
\hline & \multicolumn{4}{|c|}{ Average monthly return between Apr-Nov 2014} \\
\hline & (1) & (2) & (3) & (4) \\
\hline \multirow[t]{2}{*}{ Intercept } & $0.049 * * *$ & $0.055 * * *$ & $0.074 * *$ & 0.010 \\
\hline & $(0.006)$ & $(0.008)$ & $(0.035)$ & $(0.037)$ \\
\hline \multirow[t]{2}{*}{ Invest } & $-0.020 * * *$ & $-0.021 * * *$ & -0.037 & 0.039 \\
\hline & $(0.007)$ & $(0.007)$ & $(0.037)$ & $(0.039)$ \\
\hline \multirow[t]{2}{*}{ Difcov } & 0.191 & -0.180 & 1.044 & -0.336 \\
\hline & $(1.662)$ & $(1.698)$ & $(1.693)$ & $(1.767)$ \\
\hline \multirow[t]{2}{*}{ Difcov*Invest } & $3.797 * *$ & $3.982 * *$ & $3.721 * *$ & $5.560 * * *$ \\
\hline & $(1.856)$ & $(1.901)$ & $(1.887)$ & $(2.064)$ \\
\hline \multirow[t]{2}{*}{ Size*Invest } & & & 0.000 & 0.000 \\
\hline & & & $(0.001)$ & $(0.001)$ \\
\hline \multirow[t]{2}{*}{ Size*(1-Invest) } & & & 0.002 & -0.002 \\
\hline & & & $(0.004)$ & $(0.004)$ \\
\hline \multirow[t]{2}{*}{ Turnover*Invest } & & & $-0.003 * * *$ & $-0.003 * * *$ \\
\hline & & & $(0.001)$ & $(0.001)$ \\
\hline \multirow[t]{2}{*}{ Turnover*(1-Invest) } & & & $-0.003 * * *$ & $-0.005 * * *$ \\
\hline & & & $(0.001)$ & $(0.001)$ \\
\hline \multirow[t]{2}{*}{ BooktoMarket*Invest } & & & & $-0.010 *$ \\
\hline & & & & $(0.005)$ \\
\hline \multirow[t]{2}{*}{ BooktoMarket*(1-Invest) } & & & & 0.002 \\
\hline & & & & $(0.006)$ \\
\hline \multirow{2}{*}{ Damean*Invest } & & & & 0.032 \\
\hline & & & & $(0.170)$ \\
\hline \multirow{2}{*}{ Damean*(1-Invest) } & & & & $0.511 * *$ \\
\hline & & & & $(0.232)$ \\
\hline \multirow[t]{2}{*}{ Dasd*Invest } & & & & -0.018 \\
\hline & & & & $(0.078)$ \\
\hline \multirow[t]{2}{*}{ Dasd*(1-Invest) } & & & & $0.294 * *$ \\
\hline & & & & $(0.121)$ \\
\hline \multirow[t]{2}{*}{ Instowner*Invest } & & & & -0.006 \\
\hline & & & & $(0.005)$ \\
\hline \multirow[t]{2}{*}{ Instowner*(1-Invest) } & & & & -0.009 \\
\hline & & & & $(0.008)$ \\
\hline Slope of Difcov for Investibles & 3.99 & 3.80 & 4.76 & 5.22 \\
\hline Industry fixed effects & No & Yes & Yes & Yes \\
\hline R-squared & 0.040 & 0.058 & 0.101 & 0.138 \\
\hline
\end{tabular}

${ }^{\mathrm{a}} \mathrm{N}=786$. Coefficients on industry fixed effects are not reported. Difcov is computed using monthly time series data over the five years (or up to the IPO date, whichever is later) prior to the first month of the sample frame. Invest is a dummy variable that is equal to one for investible stocks and zero otherwise. Size is defined as the logarithmic transformation of the market capitalization of the stock as a proportion to that of the market portfolio prior to the policy implementation date. Turnover is defined as the ratio of total dollar value of the stock traded over the year ended on Nov 16, 2013 divided by the firm's market capitalization. BooktoMarket is the ratio of the total book value to the market capitalization of the firm prior to the implementation date. Damean (Dasd) is the mean (standard deviation) of the monthly returns of the stock over the five years (or up to the IPO date, whichever is later) prior to the first month of the sample frame. Instowner is the fraction of institutional investors who own the stock prior to the implementation date. Robust standard errors are given in parentheses. *, Significant at the 10 percent level; **, significant at the 5 percent level; ***, significant at the 1 percent level. 
TABLE III

SENSITIVITY ANALYSIS: ALTERNATIVE SAMPLE FRAMES ${ }^{\mathrm{a}}$

\begin{tabular}{|c|c|c|c|c|c|c|}
\hline \multirow[t]{2}{*}{$\begin{array}{l}\text { Average monthly return } \\
\text { between: }\end{array}$} & \multicolumn{2}{|c|}{$\begin{array}{c}\text { Announcement month } \\
{[-6,-1] \text { Window }}\end{array}$} & \multicolumn{2}{|c|}{$\begin{array}{c}\text { Implementation month } \\
{[-5,0] \text { Window }}\end{array}$} & \multicolumn{2}{|c|}{$\begin{array}{c}\text { Implementation month } \\
{[0,+5] \text { Window }}\end{array}$} \\
\hline & (1a) & (1b) & (2a) & $(2 b)$ & (3a) & (3b) \\
\hline \multirow[t]{2}{*}{ Intercept } & 0.008 & 0.031 & $0.078 * * *$ & 0.054 & $0.073 * * *$ & $0.159 * * *$ \\
\hline & $(0.009)$ & $(0.034)$ & $(0.009)$ & $(0.044)$ & $(0.008)$ & $(0.033)$ \\
\hline \multirow[t]{2}{*}{ Invest } & $-0.014 *$ & -0.058 & $-0.026 * * *$ & 0.002 & 0.009 & -0.007 \\
\hline & $(0.008)$ & $(0.037)$ & $(0.009)$ & $(0.046)$ & $(0.009)$ & $(0.037)$ \\
\hline \multirow[t]{2}{*}{ Difcov } & -0.735 & 0.699 & -0.906 & -1.825 & -1.177 & 1.653 \\
\hline & (1.324) & $(1.487)$ & (2.039) & (2.159) & $(2.422)$ & $(3.045)$ \\
\hline \multirow[t]{2}{*}{ Difcov*Invest } & 0.290 & 0.915 & $4.989 * *$ & $5.905 * *$ & 1.123 & 1.536 \\
\hline & $(1.460)$ & $(1.716)$ & $(2.235)$ & $(2.477)$ & (3.053) & $(3.762)$ \\
\hline \multirow[t]{2}{*}{ Size*Invest } & & $-0.007 * * *$ & & 0.000 & & $0.009 * * *$ \\
\hline & & $(0.002)$ & & $(0.002)$ & & $(0.002)$ \\
\hline \multirow[t]{2}{*}{ Size*(1-Invest) } & & 0.002 & & 0.000 & & $0.009 * * *$ \\
\hline & & $(0.003)$ & & $(0.004)$ & & $(0.003)$ \\
\hline \multirow[t]{2}{*}{ Turnover*Invest } & & $-0.006 * * *$ & & $-0.003 * * *$ & & -0.008 \\
\hline & & $(0.001)$ & & $(0.001)$ & & $(0.001)$ \\
\hline \multirow[t]{2}{*}{ Turnover*(1-Invest) } & & $-0.005 * * *$ & & $-0.004 * * *$ & & 0.000 \\
\hline & & $(0.001)$ & & $(0.001)$ & & $(0.001)$ \\
\hline \multirow[t]{2}{*}{ BooktoMarket*Invest } & & -0.010 & & -0.005 & & 0.012 \\
\hline & & $(0.007)$ & & $(0.007)$ & & $(0.008)$ \\
\hline \multirow[t]{2}{*}{ BooktoMarket*(1-Invest) } & & $-0.013 *$ & & 0.003 & & 0.006 \\
\hline & & $(0.007)$ & & $(0.009)$ & & $(0.008)$ \\
\hline \multirow[t]{2}{*}{ Damean*Invest } & & $0.872 * * *$ & & -0.081 & & $-0.600 * * *$ \\
\hline & & $(0.215)$ & & $(0.209)$ & & $(0.225)$ \\
\hline \multirow[t]{2}{*}{ Damean*(1-Invest) } & & $0.759 * * *$ & & 0.332 & & -0.410 \\
\hline & & $(0.258)$ & & $(0.293)$ & & $(0.292)$ \\
\hline \multirow[t]{2}{*}{ Dasd*Invest } & & $-0.204 *$ & & 0.084 & & -0.146 \\
\hline & & $(0.113)$ & & $(0.100)$ & & $(0.098)$ \\
\hline \multirow[t]{2}{*}{ Dasd*(1-Invest) } & & 0.055 & & $0.345 * *$ & & -0.188 \\
\hline & & $(0.115)$ & & $(0.151)$ & & $(0.122)$ \\
\hline \multirow[t]{2}{*}{ Instowner*Invest } & & 0.000 & & $-0.010 *$ & & -0.003 \\
\hline & & $(0.006)$ & & $(0.006)$ & & $(0.007)$ \\
\hline \multirow[t]{2}{*}{ Instowner*(1-Invest) } & & -0.009 & & -0.015 & & -0.003 \\
\hline & & $(0.007)$ & & $(0.009)$ & & $(0.008)$ \\
\hline Slope of Difcov for Invest & -0.44 & 1.61 & 4.08 & 4.08 & -0.05 & 3.19 \\
\hline Industry fixed effects & Yes & Yes & Yes & Yes & Yes & Yes \\
\hline R-squared & 0.114 & 0.258 & 0.069 & 0.115 & 0.096 & 0.190 \\
\hline
\end{tabular}

${ }^{a} \mathrm{~N}=786$. Announcement month [0] is April 2014 and implementation month [0] is November 2014. Coefficients on industry fixed effects are not reported. Difcov is computed using monthly time series data over the five years (or up to the IPO date, whichever is later) prior to the first month of the sample frame. Invest is a dummy variable that is equal to one for investible stocks and zero otherwise. Size is defined as the logarithmic transformation of the market capitalization of the stock as a proportion to that of the market portfolio prior to the policy implementation date. Turnover is defined as the ratio of total dollar value of the stock traded over the year ended on Nov 16, 2013 divided by the firm's market capitalization. BooktoMarket is the ratio of the total book value to the market capitalization of the firm prior to the implementation date. Damean (Dasd) is the mean (standard deviation) of the monthly returns of the stock over the five years (or up to the IPO date, whichever is later) prior to the first month of the sample frame. Instowner is the fraction of institutional investors who own the stock prior to the implementation date. Robust standard errors are given in parentheses. *, Significant at the 10 percent level; **, significant at the 5 percent level; ***, significant at the 1 percent level. 
TABLE IV

Quantile Regression Results ${ }^{\mathrm{a}}$

\begin{tabular}{|c|c|c|c|c|c|c|c|c|c|}
\hline Percentile & $\begin{array}{c}\text { 10th } \\
(1)\end{array}$ & $\begin{array}{l}20 \text { th } \\
(2)\end{array}$ & $\begin{array}{c}\text { 30th } \\
(3)\end{array}$ & $\begin{array}{c}\text { 40th } \\
(4)\end{array}$ & $\begin{array}{c}50 \text { th } \\
\text { (median) } \\
(5)\end{array}$ & $\begin{array}{c}60 \text { th } \\
(6)\end{array}$ & $\begin{array}{l}\text { 70th } \\
(7)\end{array}$ & $\begin{array}{c}80 \text { th } \\
(8)\end{array}$ & $\begin{array}{l}\text { 90th } \\
(9)\end{array}$ \\
\hline \multicolumn{10}{|c|}{ Panel A: Monthly return between Apr-Nov 2014} \\
\hline Intercept & $\begin{array}{l}0.022 * * * \\
(0.008)\end{array}$ & $\begin{array}{l}0.029 * * * \\
(0.007)\end{array}$ & $\begin{array}{l}0.033 * * * \\
(0.006)\end{array}$ & $\begin{array}{l}0.039 * * * \\
(0.006)\end{array}$ & $\begin{array}{l}0.044 \text { *** } \\
(0.007)\end{array}$ & $\begin{array}{l}0.055 * * * \\
(0.007)\end{array}$ & $\begin{array}{l}0.070 * * * \\
(0.009)\end{array}$ & $\begin{array}{l}0.081 * * * \\
(0.010)\end{array}$ & $\begin{array}{l}0.102 \text { *** } \\
(0.017)\end{array}$ \\
\hline Invest & $\begin{array}{l}-0.018 * * \\
(0.008)\end{array}$ & $\begin{array}{l}-0.015 * * * \\
(0.005)\end{array}$ & $\begin{array}{l}-0.014 * * \\
(0.006)\end{array}$ & $\begin{array}{r}-0.008 \\
(0.006)\end{array}$ & $\begin{array}{r}-0.006 \\
(0.007)\end{array}$ & $\begin{array}{l}-0.015 * * \\
(0.007)\end{array}$ & $\begin{array}{l}-0.020 * * * \\
(0.007)\end{array}$ & $\begin{array}{l}-0.022 * * * \\
(0.007)\end{array}$ & $\begin{array}{l}-0.039 * * \\
(0.014)\end{array}$ \\
\hline Difcov & $\begin{array}{r}-0.639 \\
(1.804)\end{array}$ & $\begin{array}{r}0.584 \\
(1.280)\end{array}$ & $\begin{array}{r}1.503 \\
(1.475)\end{array}$ & $\begin{array}{l}2.285 * \\
(1.329)\end{array}$ & $\begin{array}{r}1.990 \\
-(0.006)\end{array}$ & $\begin{array}{r}0.338 \\
(1.219)\end{array}$ & $\begin{array}{r}-1.848 \\
(1.735)\end{array}$ & $\begin{array}{r}-0.501 \\
(1.746)\end{array}$ & $\begin{array}{r}-0.582 \\
(3.193)\end{array}$ \\
\hline Difcov*Invest & $\begin{array}{l}4.498 * \\
(2.304)\end{array}$ & $\begin{array}{l}3.826 \text { ** } \\
(1.607)\end{array}$ & $\begin{array}{l}2.780 * \\
(1.627)\end{array}$ & $\begin{array}{r}0.704 \\
(1.551)\end{array}$ & $\begin{array}{r}0.441 \\
(1.586)\end{array}$ & $\begin{array}{c}2.883 * \\
(1.528)\end{array}$ & $\begin{array}{l}4.146 * * \\
(2.019)\end{array}$ & $\begin{array}{l}4.005 * \\
(2.123)\end{array}$ & $\begin{array}{r}5.211 \\
(3.308)\end{array}$ \\
\hline Slope of Difcov for Invest & 3.86 & 4.41 & 4.28 & 2.99 & 2.43 & 3.22 & 2.30 & 3.50 & 4.63 \\
\hline \multicolumn{10}{|c|}{ Panel B: Monthly return between Jun-Nov 2014} \\
\hline Intercept & $\begin{array}{l}0.039 * * * \\
(0.010)\end{array}$ & $\begin{array}{l}0.043 * * * \\
(0.008)\end{array}$ & $\begin{array}{l}0.056 \text { *** } \\
(0.006)\end{array}$ & $\begin{array}{l}0.056 \text { *** } \\
(0.007)\end{array}$ & $\begin{array}{l}0.068 \text { *** } \\
(0.007)\end{array}$ & $\begin{array}{l}0.074 * * * \\
(0.009)\end{array}$ & $\begin{array}{l}0.087 * * * \\
(0.012)\end{array}$ & $\begin{array}{l}0.118 \text { *** } \\
(0.015)\end{array}$ & $\begin{array}{l}0.131 \text { *** } \\
(0.020)\end{array}$ \\
\hline Invest & $\begin{array}{l}-0.013 * \\
(0.008)\end{array}$ & $\begin{array}{r}-0.011 \\
(0.008)\end{array}$ & $\begin{array}{l}-0.020 * * * \\
(0.007)\end{array}$ & $\begin{array}{l}-0.017 * * \\
(0.007)\end{array}$ & $\begin{array}{l}-0.024 * * * \\
(0.007)\end{array}$ & $\begin{array}{l}-0.022 * * \\
(0.009)\end{array}$ & $\begin{array}{l}-0.023 * * \\
(0.010)\end{array}$ & $\begin{array}{l}-0.032 * * \\
(0.013)\end{array}$ & $\begin{array}{l}-0.032 * * \\
(0.016)\end{array}$ \\
\hline Difcov & $\begin{array}{r}1.207 \\
(0.907)\end{array}$ & $\begin{array}{r}2.602 \\
(1.841)\end{array}$ & $\begin{array}{r}0.452 \\
(1.292)\end{array}$ & $\begin{array}{r}1.004 \\
(1.437)\end{array}$ & $\begin{array}{r}-0.314 \\
(1.597)\end{array}$ & $\begin{array}{r}-0.615 \\
(1.990)\end{array}$ & $\begin{array}{r}-1.471 \\
(2.025)\end{array}$ & $\begin{array}{r}-3.718 \\
(3.010)\end{array}$ & $\begin{array}{r}-1.903 \\
(2.709)\end{array}$ \\
\hline Difcov*Invest & $\begin{array}{r}1.795 \\
(2.051)\end{array}$ & $\begin{array}{r}1.434 \\
(2.107)\end{array}$ & $\begin{array}{l}3.991 * * \\
(1.780)\end{array}$ & $\begin{array}{l}4.226 * * \\
(1.715)\end{array}$ & $\begin{array}{l}5.279 \text { *** } \\
(1.788)\end{array}$ & $\begin{array}{l}4.710 * * \\
(2.268)\end{array}$ & $\begin{array}{l}4.601 * \\
(2.364)\end{array}$ & $\begin{array}{l}6.522 * \\
(3.342)\end{array}$ & $\begin{array}{l}5.415 * \\
(3.059)\end{array}$ \\
\hline Slope of Difcov for Invest & 3.00 & 4.04 & 4.44 & 5.23 & 4.97 & 4.10 & 3.13 & 2.80 & 3.51 \\
\hline
\end{tabular}

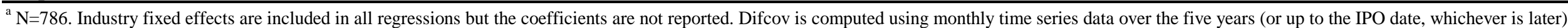

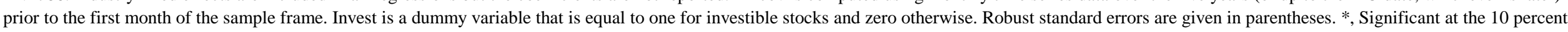
level; **, significant at the 5 percent level; ***, significant at the 1 percent level. 
TABLE V

DISTINUGUISHING BETWEEN STOCKS IN SSE180 AND SSE380 INDICES ${ }^{\mathrm{a}}$

\begin{tabular}{lcccr}
\hline \hline Average monthly return between & $\begin{array}{c}\text { Exclude } \\
\text { Apr-Nov 2014: }\end{array}$ & $\begin{array}{c}\text { Exclude } \\
\text { SSE180 }\end{array}$ & $\begin{array}{c}\text { Full } \\
\text { sample }\end{array}$ & $\begin{array}{c}\text { Full } \\
\text { sample } \\
\end{array}$ \\
\hline Intercept & -0.005 & 0.018 & 0.009 & \multicolumn{1}{c}{$(4)$} \\
& $(0.037)$ & $(0.038)$ & $(0.037)$ & 0.054 \\
Invest & 0.044 & 0.038 & 0.048 & 0.006 \\
& $(0.041)$ & $(0.044)$ & $(0.040)$ & $(0.047)$ \\
SSE180 & & & -0.013 & -0.008 \\
& & & $(0.007)$ & $(0.009)$ \\
Difcov & 0.118 & -0.470 & -0.322 & -1.808 \\
& $(1.773)$ & $(1.715)$ & $(1.770)$ & $(2.164)$ \\
Difcov*Invest & $4.863 * *$ & $6.473 * *$ & $4.727 * *$ & $5.311 * *$ \\
& $(2.173)$ & $(2.815)$ & $(2.145)$ & $(2.580)$ \\
Difcov*SSE180 & & & $3.044 *$ & 2.087 \\
& & & $(1.709)$ & $(1.973)$ \\
Slope of Difcov for Invest & 4.98 & 6.00 & & \\
Industry fixed effects & Yes & Yes & 4.41 & 3.50 \\
R-squared & 0.135 & 0.164 & 0.141 & 0.116 \\
& Apr-Nov & Apr-Nov & Apr-Nov & Jun-Nov \\
Sample frame & 2014 & 2014 & 2014 & 2014 \\
N & 656 & 446 & 786 & 786 \\
\hline
\end{tabular}

${ }^{a}$ Industry fixed effects and other control covariables are included in all regressions but the coefficients are not reported. Difcov is computed using monthly time series data over the five years (or up to the IPO date, whichever is later) prior to the first month of the sample frame. Invest is a dummy variable that is equal to one for investible stocks and zero otherwise. SSE180 is a dummy variable taking the value one for stocks that is a component of SSE180 Index, and zero otherwise. Robust standard errors are given in parentheses. *, Significant at the 10 percent level; **, significant at the 5 percent level; ***, significant at the 1 percent level. 


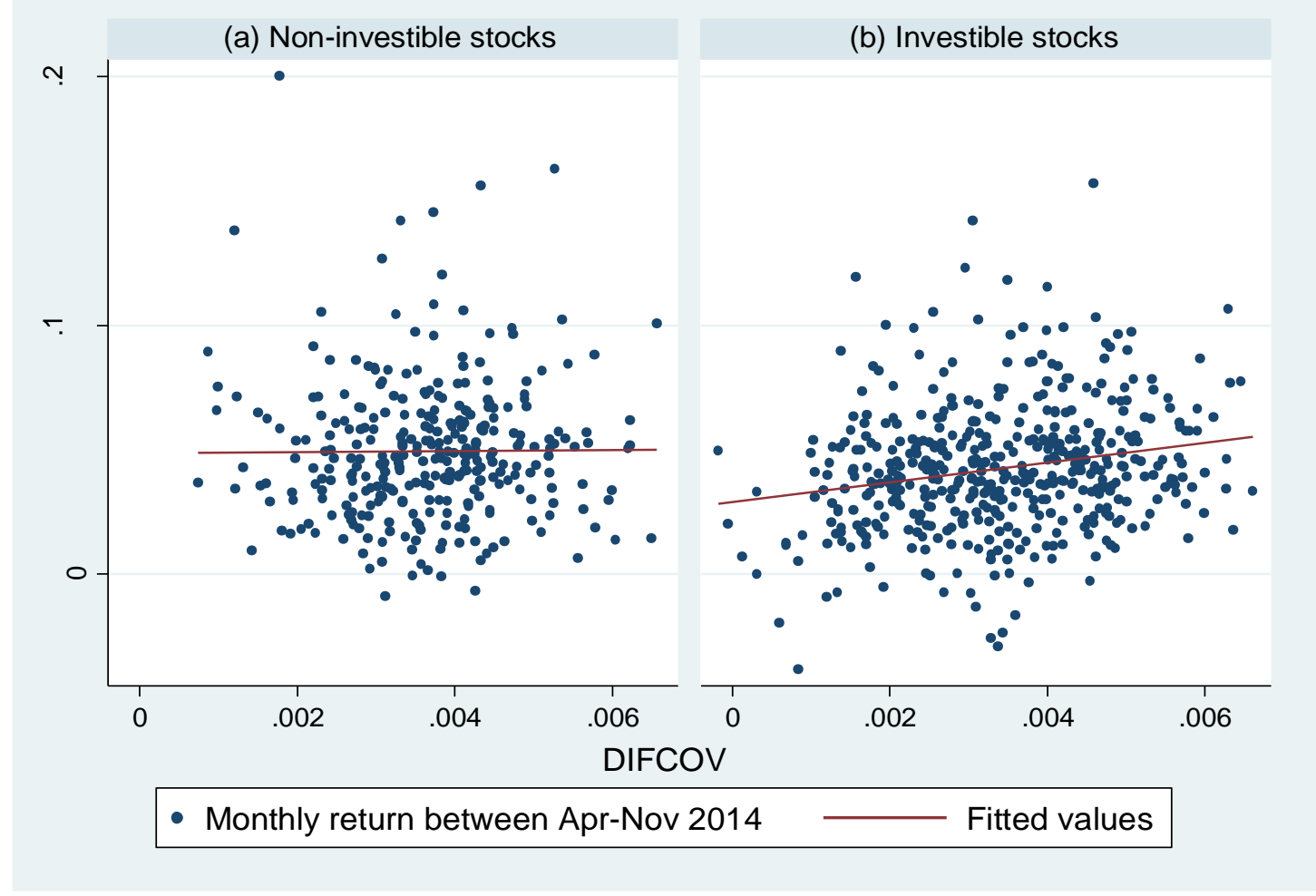

FIGURE 1. --- Stock return versus difference between covariances with the local and world markets (DIFCOV). 
APPENDIX TABLE A1

Summary Statistics of Key Variables for Stocks in SSE380 and SSE180 Indices ${ }^{\mathrm{a}}$

\begin{tabular}{|c|c|c|c|c|}
\hline Variables & Mean & St.Dev. & Min & $\overline{\operatorname{Max}}$ \\
\hline \multicolumn{5}{|l|}{ Stocks in SSE380 index $(N=340)$ : } \\
\hline Difcov & 0.0033 & 0.0013 & -0.0002 & 0.0064 \\
\hline Covariance with local market & 0.0045 & 0.0016 & 0.0005 & 0.0084 \\
\hline Covariance with world market & 0.0012 & 0.0006 & -0.0006 & 0.0029 \\
\hline Correlation with local market & 0.5809 & 0.1444 & 0.0466 & 0.9117 \\
\hline Correlation with world market & 0.1958 & 0.1151 & -0.1240 & 0.5380 \\
\hline Size & 0.0005 & 0.0003 & 0.0001 & 0.0023 \\
\hline Turnover & 2.2307 & 1.6950 & 0.1341 & 12.6923 \\
\hline Book to market ratio & 0.4391 & 0.2290 & 0.0593 & 1.4055 \\
\hline Institutional owner (\%) & 35.9456 & 25.2558 & 0.0100 & 100.0000 \\
\hline Mean of historical monthly returns (damean) & 0.0036 & 0.0094 & -0.0247 & 0.0351 \\
\hline Standard deviation of historical returns (dasd) & 0.1096 & 0.0210 & 0.0592 & 0.2055 \\
\hline Monthly return between Apr-Nov 2014 & 0.0422 & 0.0248 & -0.0381 & 0.1571 \\
\hline \multicolumn{5}{|l|}{ Stocks in SSE180 index $(N=130)$ : } \\
\hline Difcov & 0.0038 & 0.0014 & -0.0001 & 0.0066 \\
\hline Covariance with local market & 0.0050 & 0.0019 & 0.0004 & 0.0088 \\
\hline Covariance with world market & 0.0013 & 0.0006 & -0.0004 & 0.0028 \\
\hline Correlation with local market & 0.5905 & 0.1789 & 0.0817 & 0.8644 \\
\hline Correlation with world market & 0.216 & 0.1239 & -0.1426 & 0.5026 \\
\hline Size & 0.0017 & 0.0020 & 0.0002 & 0.0097 \\
\hline Turnover & 2.4034 & 1.7901 & 0.2040 & 9.3280 \\
\hline Book to market ratio & 0.4931 & 0.2879 & 0.0765 & 1.4390 \\
\hline Institutional owner (\%) & 39.4333 & 26.2538 & 1.1540 & 84.1280 \\
\hline Mean of historical monthly returns (damean) & 0.0025 & 0.0103 & -0.0191 & 0.0322 \\
\hline Standard deviation of historical returns (dasd) & 0.1136 & 0.0252 & 0.0491 & 0.1944 \\
\hline Monthly return between Apr-Nov 2014 & 0.0435 & 0.0276 & -0.0075 & 0.1230 \\
\hline
\end{tabular}

${ }^{a}$ Size is defined as the market capitalization of the stock as a proportion to that of the market portfolio prior to the policy implementation date. Turnover is defined as the ratio of total dollar value of the stock traded over the year ended on Nov 16, 2013 divided by the firm's market capitalization. BooktoMarket is the ratio of the total book value to the market capitalization of the firm prior to the implementation date. Damean (Dasd) is the mean (standard deviation) of the monthly returns of the stock over the five years (or up to the IPO date, whichever is later) prior to April 2014. 
APPENDIX TABLE A2

EXTENDED SAMPLE FRAMES ${ }^{\mathrm{a}}$

\begin{tabular}{|c|c|c|c|c|}
\hline \multirow[t]{2}{*}{ Average monthly return between: } & \multicolumn{2}{|c|}{$\begin{array}{c}\text { Announcement month } \\
{[0,+9] \text { Window }}\end{array}$} & \multicolumn{2}{|c|}{$\begin{array}{c}\text { Announcement month } \\
{[0,+12] \text { Window }}\end{array}$} \\
\hline & (1a) & (1b) & (2a) & (2b) \\
\hline Intercept & $\begin{array}{l}0.052 * * * \\
(0.008)\end{array}$ & $\begin{array}{l}0.078 * * \\
(0.036)\end{array}$ & $\begin{array}{l}0.061 \text { *** } \\
(0.006)\end{array}$ & $\begin{array}{l}0.066^{* *} \\
(0.027)\end{array}$ \\
\hline Invest & $\begin{array}{r}-0.009 \\
(0.007)\end{array}$ & $\begin{array}{r}0.036 \\
(0.039)\end{array}$ & $\begin{array}{r}-0.008 \\
(0.006)\end{array}$ & $\begin{array}{r}0.010 \\
(0.029)\end{array}$ \\
\hline Difcov & $\begin{array}{r}0.087 \\
(1.655)\end{array}$ & $\begin{array}{r}0.344 \\
(1.654)\end{array}$ & $\begin{array}{r}-0.254 \\
(1.387)\end{array}$ & $\begin{array}{r}0.728 \\
(1.432)\end{array}$ \\
\hline Difcov*Invest & $\begin{array}{l}4.003 \text { ** } \\
(1.940)\end{array}$ & $\begin{array}{l}5.191 * * \\
(2.028)\end{array}$ & $\begin{array}{r}2.180 \\
(1.610)\end{array}$ & $\begin{array}{r}2.161 \\
(1.749)\end{array}$ \\
\hline Size*Invest & & $\begin{array}{l}0.097 \text { *** } \\
(0.002)\end{array}$ & & $\begin{array}{l}0.003 * * \\
(0.001)\end{array}$ \\
\hline Size*(1-Invest) & & $\begin{array}{r}0.006 \\
(0.004)\end{array}$ & & $\begin{array}{r}0.002 \\
(0.003)\end{array}$ \\
\hline Turnover*Invest & & $\begin{array}{l}-0.003 * * * \\
(0.001)\end{array}$ & & $\begin{array}{l}-0.003 * * * \\
(0.001)\end{array}$ \\
\hline Turnover*(1-Invest) & & $\begin{array}{l}-0.004 * * * \\
(0.001)\end{array}$ & & $\begin{array}{l}-0.003 * * * \\
(0.001)\end{array}$ \\
\hline BooktoMarket*Invest & & $\begin{array}{r}0.008 \\
(0.007)\end{array}$ & & $\begin{array}{r}0.004 \\
(0.005)\end{array}$ \\
\hline BooktoMarket*(1-Invest) & & $\begin{array}{r}0.008 \\
(0.008)\end{array}$ & & $\begin{array}{r}0.004 \\
(0.006)\end{array}$ \\
\hline Damean*Invest & & $\begin{array}{l}-0.380 * * \\
(0.171)\end{array}$ & & $\begin{array}{r}-0.028 \\
(0.143)\end{array}$ \\
\hline Damean*(1-Invest) & & $\begin{array}{l}-0.029 \\
(0.222)\end{array}$ & & $\begin{array}{c}0.359 * \\
(0.183)\end{array}$ \\
\hline Dasd*Invest & & $\begin{array}{r}-0.041 \\
(0.080)\end{array}$ & & $\begin{array}{r}-0.020 \\
(0.068)\end{array}$ \\
\hline $\operatorname{Dasd}^{*}(1$-Invest $)$ & & $\begin{array}{l}0.190 * \\
(0.113)\end{array}$ & & $\begin{array}{r}0.090 \\
(0.091)\end{array}$ \\
\hline Instowner*Invest & & $\begin{array}{l}-0.002 \\
(0.005)\end{array}$ & & $\begin{array}{r}-0.005 \\
(0.004)\end{array}$ \\
\hline Instowner*(1-Invest) & & $\begin{array}{r}-0.005 \\
(0.008)\end{array}$ & & $\begin{array}{r}-0.007 \\
(0.006)\end{array}$ \\
\hline Slope of Difcov for Invest & 4.09 & 5.53 & 1.93 & 2.89 \\
\hline Industry fixed effects & Yes & Yes & Yes & Yes \\
\hline R-squared & 0.094 & 0.224 & 0.054 & 0.129 \\
\hline
\end{tabular}

${ }^{a} \mathrm{~N}=786$. Announcement month [0] is April 2014 and implementation month [0] is November 2014. Coefficients on industry fixed effects are not reported. Difcov is computed using monthly time series data over the five years (or up to the IPO date, whichever is later) prior to the first month of the sample frame. Invest is a dummy variable that is equal to one for investible stocks and zero otherwise. Size is defined as the logarithmic transformation of the market capitalization of the stock as a proportion to that of the market portfolio prior to the policy implementation date. Turnover is defined as the ratio of total dollar value of the stock traded over the year ended on Nov 16, 2013 divided by the firm's market capitalization. BooktoMarket is the ratio of the total book value to the market capitalization of the firm prior to the implementation date. Damean (Dasd) is the mean (standard deviation) of the monthly returns of the stock over the five years (or up to the IPO date, whichever is later) prior to the first month of the sample frame. Instowner is the fraction of institutional investors who own the stock prior to the implementation date. Robust standard errors are given in parentheses. *, Significant at the 10 percent level; **, significant at the 5 percent level; ***, significant at the 1 percent level. 